\title{
Functional and Quality Characteristics of Ginger, Pineapple, and Turmeric Juice Mix as Influenced by Blend Variations
}

\author{
Akama Friday Ogori ${ }^{1}$, Julius Amove ${ }^{2}$, Precious Aduloju ${ }^{2}$, Giacomo Sardo ${ }^{3}{ }^{(1)}$, \\ Charles Odilichukwu R. Okpala ${ }^{4, *(D)}$, Gioacchino Bono $^{3}$ (D) and Małgorzata Korzeniowska $^{4}$ (I) \\ 1 Department of Home Sciences, Faculty of Agriculture, Federal University Gashua, \\ Gashua P.M.B.1005, Nigeria; ogorifaraday@gmail.com \\ 2 Department of Food Science and Technology, Federal University of Agriculture Makurdi, \\ Makurdi 970211, Nigeria; amovejulius@yahoo.com (J.A.); preshus06@gmail.com (P.A.) \\ 3 Institute for Biological Resources and Marine Biotechnologies (IRBIM), National Research Council of \\ Italy (CNR), 91026 Mazara del Vallo, Italy; giacomosardo88@gmail.com (G.S.); gioacchino.bono@cnr.it (G.B.) \\ 4 Faculty of Biotechnology and Food Science, Wrocław University of Environmental and Life Sciences, \\ 51-630 Wrocław, Poland; malgorzata.korzeniowska@upwr.edu.pl \\ * Correspondence: charlesokpala@gmail.com
}

check for updates

Citation: Ogori, A.F.; Amove, J.; Aduloju, P.; Sardo, G.; Okpala, C.O.R.; Bono, G.; Korzeniowska, M. Functional and Quality Characteristics of Ginger Pineapple, and Turmeric Juice Mix as Influenced by Blend Variations. Foods 2021, 10, 525. https://doi.org/10.3390/ foods 10030525

Academic Editors: Danijela Bursać Kovačević and Predrag Putnik

Received: 31 January 2021

Accepted: 25 February 2021

Published: 3 March 2021

Publisher's Note: MDPI stays neutra with regard to jurisdictional claims in published maps and institutional affiliations.

Copyright: (C) 2021 by the authors Licensee MDPI, Basel, Switzerland. This article is an open access article distributed under the terms and conditions of the Creative Commons Attribution (CC BY) license (https:/ / creativecommons.org/licenses/by/ $4.0 /)$
Abstract: In this current work, the functional and quality characteristics of ginger, pineapple, and turmeric juice mix as influenced by blend variations were investigated. Specifically, the blends had constant ginger amounts, decreased pineapple, and increased turmeric proportionally. Additionally, the functional properties involved physicochemical ( $\mathrm{pH}$, soluble solids (SS), total titratable acidity (TA) and viscosity), proximate (moisture, protein, fat and ash), minerals ( $\mathrm{Ca}$, and $\mathrm{Mg}$ ) and vitamin $\mathrm{C}$ and $\beta$-carotene analyses, whereas quality properties involved microbiological and sensory analyses. The results showed that as quantities of pineapple and turmeric respectively decreased and increased, there was significant increases in $\mathrm{Ca}, \mathrm{Mg}$, vitamin $\mathrm{C}$, and $\beta$-carotene contents $(p<0.05)$. Across the blends, the degree of significant differences $(p<0.05)$ in the protein, fat, and ash seemed more compared to those of moisture contents. Despite the increases in $\mathrm{pH}$ and viscosity, and decreases in SS and TA, the increases in turmeric potentially reinforced by ginger most likely decreased the bacterial/fungi counts, as well as inhibition zones. Increasing and decreasing the respective amounts of turmeric and pineapple might not necessarily make the blends more acceptable, given the decreases in appearance, taste, aroma, and mouthfeel scores.

Keywords: ginger; pineapple; turmeric; juice mix; physicochemical properties; microbiological quality; sensory attributes

\section{Introduction}

Broadly, fruits can be grouped into two categories, namely: dry and fleshy/succulent fruits, and this is largely based on the physical ripe condition [1]. When properly harvested, fruits like orange, pineapple, and watermelon are edible, fleshy, and sweet [2]. Processing of fruit involve enzymes, extraction, and evaporation activities. Additionally, the suitability of a fruit juice and its concentrate/extract for an intended application remains dependent on its quality [1]. Fruits endocarps and mesocarps contain various phytochemical compounds resembling vegetables, with higher amounts of free waters, but lower amounts of carbohydrate, fat, and protein [3]. When the natural liquid of freshly harvested fruit like orange is squeezed, a juice drink is produced and is available for immediate consumption [1]. The regular consumption of fruits and its juices, most importantly, helps to make up for diet nutritional losses as well as maintain health and wellbeing [4]. Anticipating how the freshness of fruit (as well as vegetable) quality in the form of juice drink would continually keep remains challenging [1].

The relatively high metabolic activity in fruits like apple, banana, and pineapple, for instance, continues even after harvesting, which makes them highly perishable [5]. 
Among the above-mentioned fruits, pineapple (Ananas comosus) stands unique because it is among the few bromeliads that produce edible fruits, with morphologically fused berries around a central core [6]. Pineapples comprise antioxidants/polyphenolic compounds, natural enzymes, and pro-vitamins [4,7]. Specifically, a ripe and ready-to-harvest pineapple would have (above-mentioned) berries comprise bioactive and phenolics contents/nontoxic compounds, which presents promising therapeutic potentials that help to enhance immune response [6]. Essentially, the fleshy and juicy pulp makes pineapple an excellent blend to obtain new flavours in beverages and juice mixes. Moreover, mixed juice blends produced from various fruits can help combine basic nutrients and provide improved nutritional value [4].

Ginger (Zingiber officinale Rosc) is an underground rhizome or stem of herbaceous perennial species of family Zingiberaceae, also considered typically indigenous to many tropical/subtropical countries [8-10]. As a widely established monocotyledon herb, the main products of ginger include dry or fresh rhizome, as well as ground ginger (powder) [9-11]. It can also be used as a whole juice extract and in drink/tea after blending process [12]. The rhizome/stem of ginger, in addition to comprising such proximate components like ash, carbohydrate, fiber, moisture, and protein, has volatile oil of stem that contributes to provide its pleasant aroma [10,13-15]. Additionally, ginger contains ascorbic acid, $\beta$-carotene, curcumin, gingerol, linalool, paradol, $\gamma$-terpinene, as well as terpinen-4-ol [10,16-19]. The swollen rhizome/stem of ginger has been associated with antimicrobial, anti-inflammatory, and anti-carcinogenic properties [12].

Turmeric (Curcuma longa Linn.), equally an underground rhizome like ginger, and within the family of Zingiberaceae, is largely available either in dry or fresh forms $[10,20]$. Turmeric, largely cultivated across warm climatic regions of the globe, serves as a common food additive mostly in powdered form. Turmeric (powdered), positioned as a colorant, can serve as a flavouring agent in food formulations [21,22]. Commonly grown in many parts of Nigeria, the production of turmeric has made its sales provide economic and regional benefits [23]. To convert turmeric into a stable commodity, there is need for a number of processing operations, which includes boiling, cleaning, slicing, curing, drying, grading, milling, and packaging [24]. For emphasis, turmeric not only fortifies the drinks that it is added to, it is also able to improve the nutritional quality [23]. Besides its role as spice, food preservative, and coloring material, turmeric occupies a space in traditional medicine given the many scientific studies that revealed its many bioactivities like anti-inflammatory, anti-bacterial, anti-carcinogenic, anti-diabetes, and antioxidant capacities [25]. Largely, turmeric comprises $60 \%$ turmerone, $25 \%$ zingiberene, and $1.5-5 \%$ volatile oil. In particular, turmeric comprises three curcuminoids, namely: bisdemethoxycurcumin $(0.30-9.10 \%)$, curcumin (diferuloylmethane) (71.50-94\%), and demethoxy-curcumin (6-19.4\%), which cumulates to the curcuminoids $(2.5-8 \%)$ that bring about the yellow coloration [10,26,27].

Blending spices with fruits to form a juice mix is becoming increasingly popular in Nigeria, with high promise of spreading to the West Africa sub-region. Additionally, there is increasing notion among many that ginger, pineapple, and turmeric juice mix is affordable, nutritionally enriching, as well as filling, and this is yet to be scientifically verified. To our best knowledge, the blend variations of ginger, pineapple, and turmeric juice mix has not been studied. It is anticipated that a juice mix of this type could result in a nourishing composite with promising functional and sensory qualities. To supplement existing information, the aim of this current study was to determine the functional and quality characteristics of ginger, pineapple, and turmeric juice mix as influenced by blend variations. Specifically, the functional properties involved minerals and vitamins, physicochemical, and proximate components, whereas quality properties involved microbiological and sensory components.

\section{Materials and Methods}

\subsection{Overview of Experimental Program}

The schematic overview of the experimental program, depicting the essential stages from the collection of ginger, pineapple and turmeric, and preparation of individual 
juices, to the formulation to make the mix juice, and then, the functional and quality analyses, is given in Figure 1. For emphasis, this current study specifically targeted determining the functional and quality characteristics of ginger, pineapple, and turmeric juice mix as influenced by blend variations. Specifically, the functional properties involved minerals and vitamins and physicochemical and proximate components, whereas quality properties involved microbiological and sensory components. The end goal is to achieve a juice mix that could bring about a nourishing composite with promising functional and sensorial attributes.

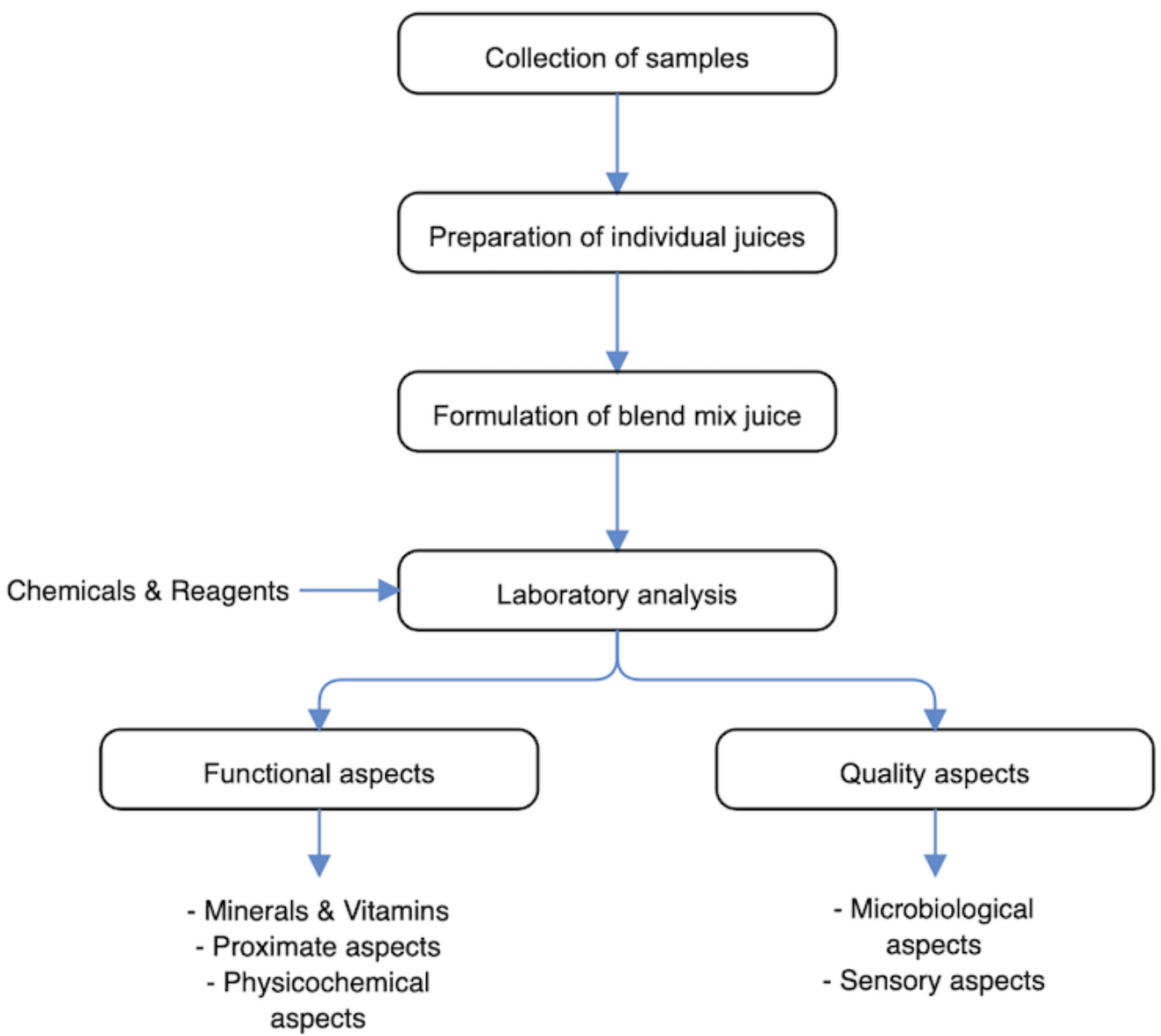

Figure 1. The schematic overview of the experimental program, depicting the essential stages from the collection of ginger, pineapple and turmeric, and preparation of individual juices, to the formulation to make the mix juice, and then, the functional and quality aspects of the laboratory analyses.

\subsection{Collection of Samples}

The ripe pineapple, matured turmeric, and ginger were purchased from the Railway $\left(7.72732^{\circ} \mathrm{N}, 8.53193^{\circ} \mathrm{E}\right)$ and Wadata $\left(7.74527^{\circ} \mathrm{N}, 8.51339^{\circ} \mathrm{E}\right)$ markets situated in Makurdi, Benue State, Nigeria. All samples were taken to the laboratory for sample preparation and analysis.

\subsection{Chemicals and Reagents}

All the chemicals and reagents utilized in this current study were reagent grade standard.

\subsection{Preparation of Pineapple Fruit Juice}

The preparation of pineapple fruit juice followed the method of Okwori et al. [28] with slight modifications, depicted in Figure 2. Pineapple fruits were selected and washed with $5 \% \mathrm{HOCl}$ solution and thoroughly rinsed with distilled water before peeling with a sterilized knife. The fruits are cut into sizes of about 3-4 mm thick and juice extraction 
using a juice extractor. The pineapple juice was filtered using sterile muslin cloth, which was folded into two layers and filtered into a clean transparent bowl. The juice was filled into an air-tight screwed cap, pasteurized, and refrigerated at $\sim 4{ }^{\circ} \mathrm{C}$ prior to analysis.

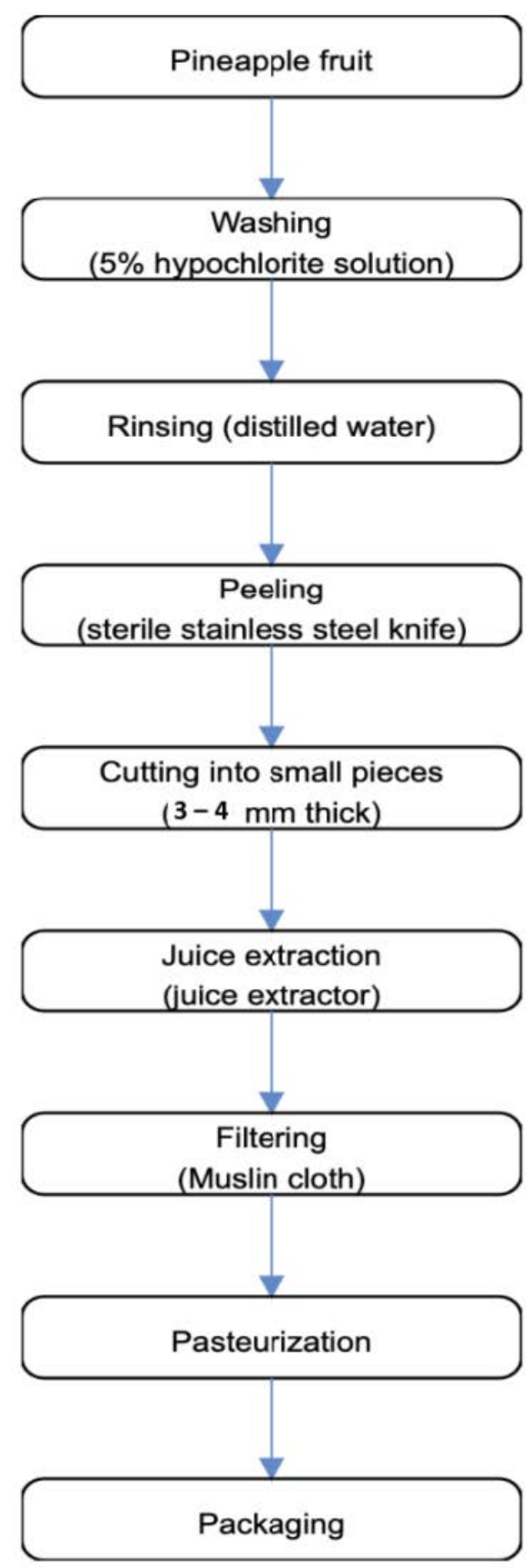

Figure 2. The preparation of pineapple fruit juice (Okwori et al., [28]).

\subsection{Preparation of Turmeric and Ginger Juice}

Following the method prescribed by the Top 10 Home Remedies Team [29], herein depicted in Figure 3, five fresh turmeric rhizomes were rinsed under clean running tap water to remove the dirts. The turmeric rhizomes were peeled and then cut into pieces and put into the blender, and at the same time, supplemented little equivalents of clean/filtered water were added to ease friction during blending. The juice pulp was then filtered using a sterile muslin cloth to get the juice, which was subsequently refrigerated at $\sim 4{ }^{\circ} \mathrm{C}$, until required. 


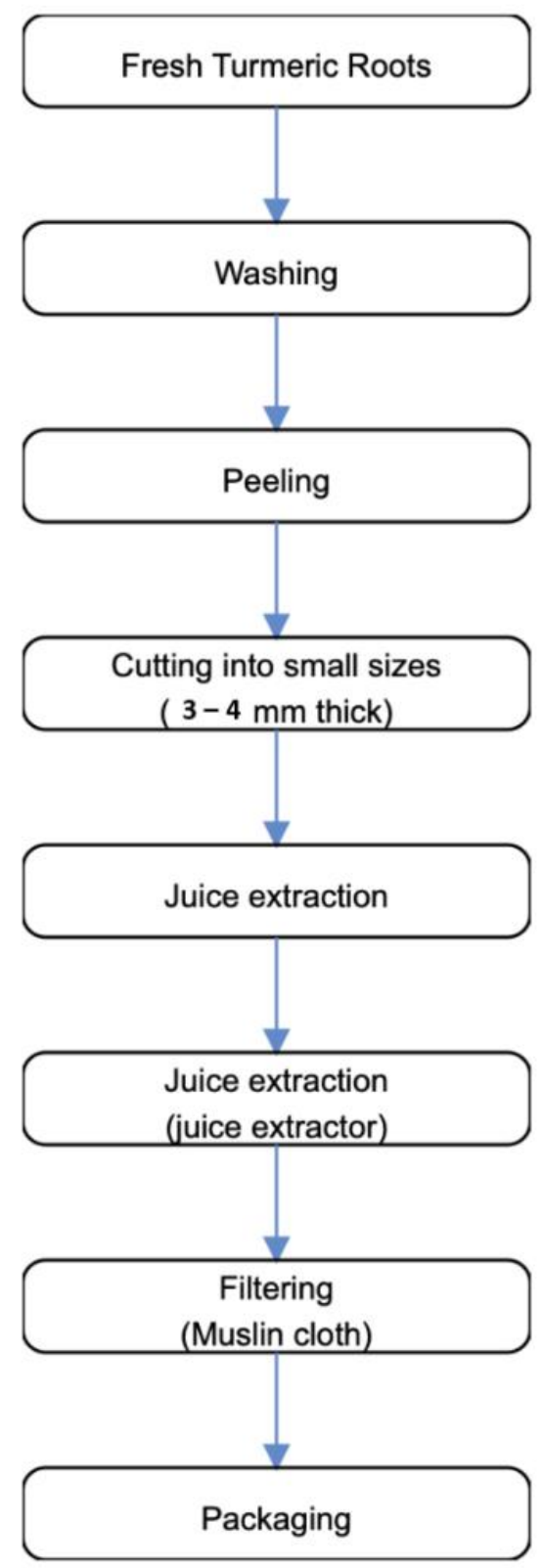

Figure 3. The preparation of turmeric juice (Source: Top 10 Home Remedies Team [29]).

The preparation of ginger juice is similar to that of turmeric juice. Fresh ginger roots were washed under clean running tap water, peeled, and then cut into smaller pieces, thereafter, they were subjected to blending, and at the same time, supplemented with little amounts of clean/filtered water to ease friction during blending. The juice pulp was then filtered using a sterile muslin cloth to get the juice, which was then refrigerated at $\sim 4{ }^{\circ} \mathrm{C}$, until required.

\subsection{Formulation of Pineapple, Turmeric and Ginger Blend Juice Mix}

The formulation of pineapple, turmeric, and ginger blend juice mix is given in Table 1. The juice from pineapple, turmeric, and ginger juices were blended at varied proportions. This followed the method demonstrated by local artisans, but with slight modifications to enable reproducibility. Specifically, the control sample was pineapple only, that is, PJ:TJ:GJ = 100:0:0. The blends kept the ginger amounts constant, decreased the pineapple and increased the turmeric amounts by proportion. Next, the juice blends were mixed by stirring, bottled with screw caps before the pasteurization at $65^{\circ} \mathrm{C}$ for $5 \mathrm{~min}$, in a thermostatically controlled water bath, and thereafter, cooled at ambient temperature of 
about $27{ }^{\circ} \mathrm{C}$. At the end, the blend juice mix samples were refrigerated at $\sim 4{ }^{\circ} \mathrm{C}$ until required for analysis.

Table 1. Formulation of Ginger, Pineapple, and Tumeric Juice Mix by Blends.

\begin{tabular}{ccccc}
\hline Samples (PJ:TJ:GJ) & Pineapple $(\mathbf{m L})$ & Turmeric $(\mathbf{m L})$ & Ginger $(\mathbf{m L})$ & Total $(\mathbf{m L})$ \\
\hline 100:0:0 & 100 & 0 & 0 & 100 \\
80:10:10 & 80 & 10 & 10 & 100 \\
70:20:10 & 70 & 20 & 10 & 100 \\
60:30:10 & 60 & 30 & 10 & 100 \\
$50: 40: 10$ & 50 & 40 & 10 & 100 \\
\hline
\end{tabular}

PJ = Pineapple juice; TJ = Turmeric juice; GJ = Ginger juice.

\subsection{Functional Analysis.}

2.7.1. Minerals and Vitamins Measurements

Determination of $\beta$-Carotene

The $\beta$-carotene of samples was determined using the AOAC method [30]. About $5 \mathrm{~g}$ of the sample was transferred into a separating funnel and a solution containing $60 \mathrm{~mL}$ of hexane; $40 \mathrm{~mL}$ of ethanol were swirled vigorously after adding $2 \mathrm{~mL}$ of $2 \% \mathrm{NaCl}$. This was then allowed to stand for $30 \mathrm{~min}$ after which the lower layer was discarded. The absorbance of the top layer was determined at a wavelength of $460 \mathrm{~mm}$ using a spectrophotometer, using the equation below:

$$
T C=\frac{\text { absorbance }}{100 \text { specific extinction } \times \text { pathlength of the cell }}
$$

where,

TC: Total carotenoids $(\mathrm{mg})$

Molar extinction coefficient $\left(\sum\right)=15 \times 10^{-4}$

Specific extinction coefficient $\left(\sum\right)=\left(\sum \times\right.$ molar mass of $\beta$-carotene $)$

Molar mass of $\beta$-carotene $=536.88 \mathrm{~g} / \mathrm{mol}$

Path length of cell $=1 \mathrm{~cm}$

Determination of Calcium and Magnesium

The mineral composition (specific to $\mathrm{Ca}$ and $\mathrm{Mg}$ ) of samples were determined by AOAC acid digestion method [31]. Ash obtained after incineration at $600{ }^{\circ} \mathrm{C}$ was dissolved in $5 \mathrm{~mL} \mathrm{HCl}$ solution and transferred into a $50 \mathrm{~mL}$ volumetric flask. The resulting solution was made to mark with distilled water. The mineral contents were then measured using atomic absorption spectrophotometer (AAS), and mineral composition results were recorded.

\section{Determination of Vitamin C}

The vitamin $C$ of samples was determined using the method described by Ikewuchi and Ikewuchi [32]. The quantities of vitamin $C$ present are measured by the tiny additions of acidified starch (termed "reaction mix"), followed by droplets of iodine until purple color. Any vitamin $C$ will "neutralize" the iodine, to prevent the purple color formation. In line with this, iodine solution $(0.1 \mathrm{M})$ was prepared using $10 \mathrm{~g}$ of $\mathrm{KI}$, and starch solution, using $0.25 \mathrm{~g}$ of starch powder. In order to actualize the vitamin C, a blank solution $(25 \mathrm{~mL})$ was made from the sample, and 10 drops of starch solution were added. The mixture was titrated with iodine solution until the first black blue color, which persisted for $\sim 20 \mathrm{~s}$. Blended juice samples $(25 \mathrm{~mL})$ were titrated exactly the same way as the standard solution. The initial and final volume of iodine solution required to produce the color change at the end points were recorded. Subsequently, the vitamin $C$ concentration was determined as follows: 
where

$\mathrm{b}=$ titre $(\mathrm{mL})$ from the titration of the standard vitamin $\mathrm{C}$ solution

$\mathrm{y}=$ titre $(\mathrm{mL})$ from the titration of the sample solution.

2.7.2. Proximate Measurements

Determination of Moisture

The moisture of samples is determined by the AOAC method [31]. Cleaned crucible is dried in the oven at $100{ }^{\circ} \mathrm{C}$ for $1 \mathrm{~h}$ to constant weight and then cooled in the desiccator. Approximately $2 \mathrm{~g}$ of the samples were weighed into the crucible and dried at $100{ }^{\circ} \mathrm{C}$ to a constant weight, and calculated as below:

$$
\% \text { Moisture }=\frac{\text { Weightloss } \times 100 \%}{\text { Weight of samples }}
$$

Determination of Crude Protein

The crude protein of samples was determined using the AOAC method [31] with slight modifications. Approximately $1 \mathrm{~g}$ of the sample was placed with a selenium catalyst in the micro Kjeldahl digestion flask. The mixture was digested to clean clear solution. The flask was cooled and then diluted with distilled water to the $50 \mathrm{~mL}$ mark of a conical flask, $5 \mathrm{~mL}$ of the mixture was transferred into distillation apparatus, and $5 \mathrm{~mL}$ of $2 \%$ boric acid added unto $100 \mathrm{~mL}$ conical flask (the receiver flask) with four drops of methyl red indicator. Then, $50 \%$ of $\mathrm{NaOH}$ was constantly added to the digested sample until the solution turned cloudy, indicating the solution had achieved alkalinity. Distillation was carried out in the boric acid solution at the receiver flask. During the distillation process, the pink color of the solution in the receiver flask turned blue, indicating the presence of ammonia. The resulting solution in the conical flask was then titrated with $0.1 \mathrm{M} \mathrm{HCl}$ and the protein content calculated as below:

$$
\begin{gathered}
\% \text { Nitrogen } \times 6.25(1 \mathrm{~mL} \text { of } 0.1 \mathrm{NHCL}=0.0014 \mathrm{gN}) \\
\text { Nitrogen }=\frac{\text { Titrevalue }- \text { blank } \times 0.0014 \mathrm{~N} \times 100 \% \times 25}{\text { Weight of sample } \times 5 \text { mlaliquot }}
\end{gathered}
$$

Determination of Crude Fat

The crude fat of samples was determined using the AOAC method [31] with slight modifications. The $100 \mathrm{~mL}$ beaker used was washed and dried in an oven for $1 \mathrm{~h}$ at $105^{\circ} \mathrm{C}$, and thereafter cooled in a desiccator and weighed. Approximately $10 \mathrm{~mL}$ of the samples was mixed with hexane in a separating funnel, and the organic layer was transferred into the pre-weighed beaker, subject to water bath, and thereafter weighed. The crude fat was determined using the equation below:

$$
\% \text { crudelipid }=\frac{\text { Weight of the fat } \times 100 \%}{\text { Weight of the sample }}
$$

\section{Determination of Ash}

The ash of samples was determined from the loss in weight during incineration following the AOAC method [30] with slight modifications. This method allows the entire organic matter to be burnt off, without the appreciable decomposition of the ash constituent. Approximately $5 \mathrm{~g}$ of the samples were placed in the incinerator. The ashing was done at a furnace of $600^{\circ} \mathrm{C}$ for $6 \mathrm{~h}$ and calculated as below:

$$
\text { Ash Content }=\frac{\text { Weight of ash } \times 100 \%}{\text { Weight of the sample }}
$$




\subsubsection{Physicochemical Measurements}

Determination of $\mathrm{pH}$

The $\mathrm{pH}$ of samples was determined using a $\mathrm{pH}$ meter, calibrated with buffers standard. The electrode was rinsed with distilled water, the electrode was then dipped into $5 \mathrm{~g}$ of the sample, which had been dissolved in $50 \mathrm{~mL}$ of water.

\section{Determination of Soluble Solids}

The soluble solids of samples were determined using the AOAC method [30]. The prism of the refractometer was cleaned and a drop of the blended juice was placed on the prism and closed. The ${ }^{\circ}$ Brix was read using the scale of the refractometer when held close to the eyes.

\section{Determination of Titratable Acid (TA)}

The titratable acid of samples was determined using the AOAC method [30] with slight modifications. Approximately $10 \mathrm{~mL}$ of the juice was pipetted into a conical flask and $25 \mathrm{~mL}$ of distilled water added to make a solution. Approximately $200 \mathrm{~mL}$ of 0.1 $\mathrm{M}$ of $\mathrm{NaOH}$ was titrated against the sample using phenolphthalein as an indicator, to achieve color pink as an end point. The corresponding burette reading was taken using the following formula:

$$
T A=\frac{\text { Titre } \times \text { blank } \times \text { Normality of base } \times \text { mlequivalent of citricacid }}{\text { Weight of Sample }}
$$

where, $T A=$ titrable acidity $(\%)$

\section{Determination of Viscosity}

The juice samples viscosity was determined using a Brookfield viscometer (model Lv-3, Middleboro, MA 02346, USA) with the spindle set at $60 \mathrm{rpm}$, after which the readings were recorded in millipascal-second (mPa.s).

\subsection{Quality Analysis}

\subsubsection{Microbiological Evaluation}

Microbiological analysis of the juice mix was carried out following the method described by Adegoke [33], with slight modifications, following the pour-plate method. This enabled the determinations of total bacteria and fungi counts. Homogenized ( $\sim 60 \mathrm{~s})$ quantities of blend $(\sim 2 \mathrm{~g})$ with $15 \mathrm{~mL}$ of diluents was prepared. Serial ten-fold dilution of homogenate involved $0.1 \mathrm{~mL}$ of aliquots aseptically introduced into sterile Petri dishes, after which molten agar $\left(\sim 45^{\circ} \mathrm{C}\right)$ was poured unto them, mixed and then allowed to set. The different agar plates were incubated for $\sim 24 \mathrm{~h}$. Nutrient Agar (NA) was used for the enumeration of total bacteria count and was then incubated at $37^{\circ} \mathrm{C}$ for $24-48 \mathrm{~h}$. Sabourd Dextrose Agar (SDA) was used for the enumeration of total fungi count then incubated at room temperature $\left(28 \pm 2{ }^{\circ} \mathrm{C}\right)$ for $3-5$ days. The microbiological analysis were reported in terms of logarithm of colony forming units $(\log \mathrm{cfu} / \mathrm{mL})$ of the blend sample.

Antibacterial activity of the juice extracts was determined by molten Agar well diffusion technique following the method of Abubakar et al. [34] with slight modifications. The test organism (Salmonella typhii) was diluted with Muller Hinton broth to $0.5 \%$ McFarland equivalent standard. Approximately $25 \mathrm{~mL}$ of Mueller Hinton Agar (HiMedia) plates were checked for sterility and streaked with an overnight broth cultured of bacterial isolate, using sterile cotton buds. A standard sterile cock borer of $6 \mathrm{~mm}$ diameter was used to make uniform wells on the surface of the streaked agar media. With the aid of a micropipette, the wells were filled up with $200 \mu \mathrm{L}$ each of the undiluted blended juice extract (sample A-E). The plates were then allowed to stand for $\sim 1 \mathrm{~h}$ in the refrigerator to allow proper diffusion of the extract. Amoxycillin $(\sim 25 \mathrm{mg} / \mathrm{mL})$ solution was prepared and served as the control [31]. Following the method of Rahman et al. [35], all the plates were incubated at $37^{\circ} \mathrm{C}$ 
for $\sim 24 \mathrm{~h}$, after which the antibacterial activity was evaluated based on the diameters of zones of inhibition and recorded in millimeter $(\mathrm{mm})$.

\subsubsection{Sensory Evaluation}

The ginger, pineapple, and turmeric juice mix blends were subjected to sensorial evaluation. This was done with the help of $10(N=10)$ panelists, comprising of students and staff of the Food Science and Technology Department, Federal University of Agriculture Makurdi. Specifically, these panelists underwent sensorial training prior to their participation at this study. Importantly, the panelists' participation was voluntary. Additionally and prior to their participation, the verbal consent was taken from all the panelists. To ensure privacy, gender was not indicated. The selection criteria was based on complete participation of sensory training for this study. The samples were presented in a white plastic cup to each panelist. Each sample presented was coded. Essentially, each panelist was provided with adequate space to ensure there was no co-operation during the sampling of juice mix blends. The sensory attributes comprised appearance, taste, aroma, mouthfeel, and general acceptability. Consistent with the method described by Iwe [36], the sensory attributes were individually considered based on a 9-point Hedonic scale, which had the least value (numeric value $=1$ ) designated as 'disliked extremely', and the highest value (numeric value $=9$ ) designated as 'liked extremely'.

\subsection{Statistical Analysis}

One-way analysis of variance (ANOVA) was used to analyse the emergent data. The results were presented in terms of mean values \pm standard deviation (SD) from duplicate measurements. The mean values were resolved with the help of Fisher's Least Significant Difference (LSD). The probability level of statistical significance was set at $p<0.05$ (95\% confidence interval). IBM SPSS software (version 22.0) was used to do the data analysis.

\section{Results and Discussion}

\subsection{Functional Aspects Minerals and Vitamins Variations}

The minerals and vitamins variations of ginger, pineapple, and turmeric juice mix as influenced by blends can be seen in Table 2. Clearly, significant differences $(p<0.05)$ in Ca, $\mathrm{Mg}$, vitamin $\mathrm{C}$, and $\beta$-carotene contents were found across samples. Specifically, the $\mathrm{Ca}, \mathrm{Mg}$, vitamin $C$, and $\beta$-carotene contents increased significantly $(p<0.05)$ as quantities of pineapple and turmeric were respectively decreased and increased. The control PJ:TJ:GJ = 100:0:0 obtained the lowest values for $\mathrm{Ca}(7.37 \pm 0.09 \mathrm{mg} / 100 \mathrm{~mL}), \mathrm{Mg}(5.37 \pm 0.07 \mathrm{mg} / 100 \mathrm{~mL})$, vitamin $C(73.60 \pm 0.71 \mathrm{mg} / 100 \mathrm{~mL})$ and $\beta$-carotene $(67.92 \pm 0.76 \mathrm{mg} / 100 \mathrm{~mL})$, compared to other samples, which showed varied ranges $(\mathrm{Ca}=$ from 8.78 to $18.09 \mathrm{mg} / 100 \mathrm{~mL}$; $\mathrm{Mg}$ = from 6.59 to $8.54 \mathrm{mg} / 100 \mathrm{~mL}$; vitamin $\mathrm{C}=$ from 86.74 to $122.97 \mathrm{mg} / 100 \mathrm{~mL}$; and $\beta$-carotene $=$ from 83.19 to $1454.10 \mathrm{mg} / 100 \mathrm{~mL}$ ). Increases in $\mathrm{Ca}, \mathrm{Mg}$, vitamin $\mathrm{C}$, and $\beta$ carotene would most likely be attributed to the addition of turmeric. The vitamin $C$ in fresh turmeric rhizome/root could show very promising levels [10,37,38]. Additionally, the vitamin $C$ in ginger could also show very promising levels [39]. Moreover, the vitamin $\mathrm{C}$ in fresh pineapple juice (control) of this current work appeared higher compared with those reported elsewhere, like $\sim 14.1 \mathrm{mg} / 100 \mathrm{~g}$ reported by Ikewuchi and Ikewuchi [32]; 22.5-33.5 mg/100 g reported by Achinewhu and Hart [40]; 52 mg/100 g reported by Rodríguez et al. [41]; and $\sim 54 \mathrm{mg} / 100 \mathrm{~g}$ reported by Chakraborty, Rao, and Misra [42]. Besides, both vitamin $C$ and $\beta$-carotene might not be responsible for the antioxidant capacity of pineapples [40]. Vitamin C would belong to hydrophilic, whereas carotenoids would belong to lipophilic antioxidants [40]. Moreover, the processing of pineapples into juice could likely be affecting, not only quantities of vitamin C [43], but also those of $\mathrm{Ca}, \mathrm{Mg}$, and $\beta$-carotene contents obtained at this current study. 
Table 2. Minerals and vitamins variations of Ginger, Pineapple, and Tumeric Juice Mix as influenced by Blends.

\begin{tabular}{|c|c|c|c|c|}
\hline \multirow{2}{*}{$\begin{array}{l}\text { Samples } \\
\text { PJ:TJ:GJ }\end{array}$} & \multicolumn{4}{|c|}{ Minerals and Vitamin Composition } \\
\hline & $\mathrm{Ca}(\mathrm{mg} / 100 \mathrm{~mL})$ & $\mathrm{Mg}(\mathrm{mg} / 100 \mathrm{~mL})$ & Vitamin C (mg/100 mL) & $\beta$-Carotene $(\mathrm{mg} / 100 \mathrm{~mL})$ \\
\hline 100:0:0 & $7.37^{\mathrm{e}} \pm 0.09$ & $5.37^{\mathrm{e}} \pm 0.07$ & $73.60^{\mathrm{d}} \pm 0.71$ & $67.92^{\mathrm{e}} \pm 0.76$ \\
\hline $80: 10: 10$ & $8.78^{\mathrm{d}} \pm 0.04$ & $6.59^{\mathrm{d}} \pm 0.01$ & $86.74^{\mathrm{c}} \pm 0.23$ & $83.19^{\mathrm{d}} \pm 3.30$ \\
\hline $70: 20: 10$ & $12.73^{\mathrm{c}} \pm 0.04$ & $7.67^{c} \pm 0.02$ & $101.81^{\mathrm{b}} \pm 0.27$ & $199.14^{\mathrm{c}} \pm 1.15$ \\
\hline $60: 30: 10$ & $15.63^{b} \pm 0.19$ & $7.89^{b} \pm 0.01$ & $103.22^{b} \pm 0.82$ & $1318.10^{\mathrm{b}} \pm 1.97$ \\
\hline $50: 40: 10$ & $18.09^{\mathrm{a}} \pm 0.01$ & $8.54^{\mathrm{a}} \pm 0.01$ & $122.98^{\mathrm{a}} \pm 1.45$ & $1454.10^{\mathrm{a}} \pm 1.69$ \\
\hline LSD & 0.257 & 0.081 & 2.65 & 5.089 \\
\hline
\end{tabular}

Values are means \pm standard deviation (SD) of duplicate determinations. Means in the same column with the same superscript are not significantly different at $(p>0.05)$, Key: PJ = Pineapple juice; TJ = Turmeric juice; GJ = Ginger juice, LSD = Least significant difference.

Proximate and Physicochemical Variations

The proximate variations of ginger, pineapple, and turmeric juice mix as influenced by blends can be seen in Table 3. Clearly, the degree of significant differences $(p<0.05)$ were more in the protein, fat, and ash compared to moisture contents across samples. The control PJ:TJ:GJ = 100:0:0 obtained the lowest values for moisture $(95.89 \pm 0.00 \%)$, crude protein $(0.008 \pm 0.001 \%)$, fat $(0.051 \pm 0.001 \%)$, and ash $(0.125 \pm 0.004 \%)$ contents, compared to the blend samples, which showed varied ranges (moisture $=$ from 96.86 to $98.18 \%$; protein $=$ from 0.013 to $0.261 \%$; fat $=$ from 0.061 to $0.168 \%$; ash $=$ from 0.287 to $0.585 \%$ ). Akusu, Kiin-Kabari and Ebere [4] reported fresh pineapple juice to have about $88 \%$ moisture, $1 \%$ crude protein, and $2 \%$ ash contents, different from values of this current study. Specifically, the increasing amounts of turmeric appears not to dramatically influence the moisture of the blend juice mix, compared to its noticeable influences on the protein, fat, and ash contents. Increases in crude fat and protein might be because of essential oils in ginger and turmeric $[10,11]$. To the consumer, increases in ash contents portrays the juice mix as a strong mineral source [44]. Ginger and tumeric generally have competitive proximate components, with ranging amounts of $7-13 \%$ moisture, $6-12 \%$ protein, $60-72 \%$ carbohydrate, and 3-7\% ash [10,13-15]. The marginal influence that increasing tumeric amounts had on moisture might strongly impact on the viscosity of the juice mix blend. Potentially, the blends PTG60:30:10 and PTG50:40:10 respectively with moisture contents of $\sim 98 \%$, would proffer higher sensorial implications compared to the others, especially on both appearance and taste attributes.

Table 3. Proximate variations of Ginger, Pineapple, and Tumeric Juice Mix as influenced by Blends.

\begin{tabular}{ccccc}
\hline Samples & \multicolumn{4}{c}{ Tested Parameters (\%) } \\
\hline P:T:G & Moisture & Protein & Fat & Ash \\
\hline PTG100:0:0 & $95.89^{\mathrm{b}} \pm 0.00$ & $0.008^{\mathrm{e}} \pm 0.001$ & $0.051^{\mathrm{e}} \pm 0.001$ & $0.125^{\mathrm{d}} \pm 0.004$ \\
PTG80:10:10 & $96.86^{\mathrm{ab}} \pm 1.37$ & $0.013^{\mathrm{d}} \pm 0.001$ & $0.061^{\mathrm{d}} \pm 0.001$ & $0.287^{\mathrm{c}} \pm 0.006$ \\
PTG70:20:10 & $97.91^{\mathrm{a}} \pm 0.01$ & $0.018^{\mathrm{c}} \pm 0.001$ & $0.072^{\mathrm{c}} \pm 0.001$ & $0.322^{\mathrm{c}} \pm 0.001$ \\
PTG60:30:10 & $98.12^{\mathrm{a}} \pm 0.21$ & $0.087^{\mathrm{b}} \pm 0.001$ & $0.101^{\mathrm{b}} \pm 0.001$ & $0.456^{\mathrm{b}} \pm 0.063$ \\
PTG50:40:10 & $98.18^{\mathrm{a}} \pm 0.07$ & $0.261^{\mathrm{a}} \pm 0.001$ & $0.168^{\mathrm{a}} \pm 0.002$ & $0.585^{\mathrm{a}} \pm 0.049$ \\
LSD & 1.597 & 0.003 & 0.007 & 0.081 \\
\hline
\end{tabular}

Values are means \pm standard deviation (SD) of duplicate determinations. Means in the same column with the same superscript are not significantly different at $(p>0.05)$; Key: PJ = Pineapple juice; TJ = Turmeric juice; $\mathrm{GJ}=$ Ginger juice; and LSD = Least significant difference.

The physicochemical variations of ginger, pineapple, and turmeric juice mix as influenced by blends can be seen in Table 4 . Clearly, there were significant differences $(p<0.05)$ found in $\mathrm{pH}, \mathrm{SS}, \mathrm{TA}$, and viscosity across samples. The control PJ:TJ:GJ = 100:0:0 obtained the least values in $\mathrm{pH}(3.81 \pm 0.007)$ and viscosity ( $300.11 \pm 0.12 \mathrm{~m}$.Pa.s), but peak values in SS $\left(11.95 \pm 0.07^{\circ}\right.$ Brix $)$ and TA $(0.9005 \pm 0.07 \%)$. Across the blends, noticeable $(p<0.05)$ increases were obtained in $\mathrm{pH}$ (from 3.83 to 4.01 ) and viscosity (from 301.68 to 850.06 m.Pa.s), whereas decreases were obtained in SS (from 9.32 to $4.90^{\circ}$ Brix) and TA (from 0.8425 to $0.5425 \%$ ). 
The physicochemical variations from increases in turmeric and decreases in pineapple amounts appear interesting. Increases in $\mathrm{pH}$ and viscosity demonstrates the impact turmeric could have in the blend juice mix [45]. Despite the increases in $\mathrm{pH}$ and decreases in TA arising from increasing amounts of turmeric [44], the blend mix juice having a peak $\mathrm{pH}$ of $\sim 4$ would appear somewhat less susceptible to microbial deterioration particularly to the most familiar neutrophilic microorganisms like Escherichia coli, staphylococci, and Salmonella spp., which are unable to thrive in acidic $\mathrm{pH}$ conditions [46]. The decreases in SS might have happened because both turmeric and ginger constituents hold less sugar content(s) compared to those of pineapple [47]. The blends' viscosity, increasing with quantities of turmeric at this study, might be attributable to its starch [48].

Table 4. Physicochemical variations of Ginger, Pineapple, and Tumeric Juice Mix as influenced by Blends.

\begin{tabular}{|c|c|c|c|c|}
\hline \multirow{2}{*}{$\begin{array}{l}\text { Samples } \\
\text { PJ:TJ:GJ }\end{array}$} & \multicolumn{4}{|c|}{ Tested Parameters } \\
\hline & $\mathrm{pH}$ & SS $\left({ }^{\circ}\right.$ Brix $)$ & TA (\%) & Viscosity (mPa.s) \\
\hline 100:0:0 & $3.81^{\mathrm{d}} \pm 0.007$ & $11.95^{\mathrm{a}} \pm 0.07$ & $0.9005^{\mathrm{a}} \pm 0.07$ & $300.11^{\mathrm{d}} \pm 0.12$ \\
\hline $80: 10: 10$ & $3.83^{c} \pm 0014$ & $9.32^{b} \pm 0.028$ & $0.8425^{b} \pm 0.35$ & $301.68^{d} \pm 0.78$ \\
\hline $70: 20: 10$ & $3.85^{c} \pm 0.001$ & $8.10^{c} \pm 0.001$ & $0.6727^{c} \pm 0.09$ & $351.06^{c} \pm 1.35$ \\
\hline $60: 30: 10$ & $3.89^{b} \pm 0.014$ & $7.42^{\mathrm{d}} \pm 0.016$ & $0.5775^{\mathrm{d}} \pm 0.21$ & $501.61^{b} \pm 2.27$ \\
\hline $50: 40: 10$ & $4.01^{\mathrm{a}} \pm 0.076$ & $4.90^{\mathrm{e}} \pm 0.004$ & $0.5425^{\mathrm{e}} \pm 0.35$ & $850.06^{a} \pm 0.06$ \\
\hline LSD & 0.024 & 0.081 & 0.0640 & 3.178 \\
\hline
\end{tabular}

Values are means \pm standard deviation (SD) of duplicate determinations. Means in the same column with the same superscript are not significantly different at $(p>0.05)$, Key: PJ = Pineapple juice; TJ = Turmeric juice; GJ = Ginger juice; LSD = Least significant difference; SS = Soluble Solids; and TA = Titratable Acid.

\subsection{Quality Aspects Microbiological Variations}

The microbiological variations of ginger, pineapple, and turmeric juice mix as influenced by blends is shown in Table 5 . Across the samples, the bacterial count ranged between $5.0 \times 10^{3}$ and $1.6 \times 10^{4} \log \mathrm{cfu} / \mathrm{mL}$, whereas the fungi count ranged between 5.0 $\times 10^{3}$ and $2.8 \times 10^{4} \log \mathrm{cfu} / \mathrm{mL}$. The blend PJ:TJ:GJ $=60: 30: 10$ obtained the highest bacterial $\left(1.6 \times 10^{4} \log \mathrm{cfu} / \mathrm{mL}\right)$ and fungi $\left(2.8 \times 10^{4} \log \mathrm{cfu} / \mathrm{mL}\right)$ counts. The increases in turmeric reduced the bacterial and fungi counts. The control sample (PJ:TJ:GJ = 100:0:0) obtained the lowest bacterial count, but not so for fungi count. Moreover, the control bacterial and fungi counts both resembled one another $(p>0.05)$. In general, both bacterial and fungi counts were below the microbiological limits prescribed by the Food and Agriculture Organization (FAO) of the United Nations for formulated foods, which is $5 \times 10^{5} \log \mathrm{cfu} / \mathrm{mL}$, which is largely applicable to both aerobic plate counts (APC) and moulds [49]. The increased turmeric amounts are strengthened by the ginger present, which might have probably brought about the decreases in bacterial counts herein, which points to the antimicrobial capacity (of turmeric).

Table 5. Microbiological variations of Ginger, Pineapple, and Tumeric Juice Mix as influenced by Blends.

\begin{tabular}{ccc}
\hline Samples (PJ:TJ:GJ) & Bacterial Count $(\log \mathbf{c f u} / \mathbf{m L})$ & Fungi Count $(\log \mathrm{cfu} / \mathrm{mL})$ \\
\hline $100: 0: 0$ & $5.0 \times 10^{3}$ & $5.0 \times 10^{3}$ \\
$80: 10: 10$ & $3.0 \times 10^{4}$ & $1.0 \times 10^{4}$ \\
$70: 20: 10$ & $1.2 \times 10^{4}$ & $8.0 \times 10^{3}$ \\
$60: 30: 10$ & $1.6 \times 10^{4}$ & $2.8 \times 10^{4}$ \\
$50: 40: 10$ & $8.0 \times 10^{3}$ & $4.2 \times 10^{3}$ \\
\hline
\end{tabular}

Values are means of duplicate determinations. Key: PJ = Pineapple juice; TJ = Turmeric juice; GJ = Ginger juice.

The antimicrobial inhibition of ginger, pineapple, and turmeric juice mix as influenced by blends, can be seen in Table 6. For emphasis, the test organism was Salmonella typhii, and the control used was amoxycillin antibiotics. The result shows that inhibition zones ranged between $12.50 \mathrm{~mm}$ (100:0:0) and NSI (No Significant Inhibition) (50:40:10) com- 
pared with the control that remained at approximately $20 \mathrm{~mm}$. For emphasis, the control helps to show how the inhibition zone faired compared with those of the blends. Clearly, the antimicrobial activity is depicted by the lowering of inhibition zone as the turmeric was increased. Although the ginger amounts were constant, there is high chance that its presence contributed in strengthening the decreases in the inhibition zones at this study. Spices generally demonstrate antimicrobial activity against bacteria, yeast, molds, and viruses, given its diverse phytochemical components (e.g., alcohols, aldehydes, ethers, hydrocarbons, ketones, as well as phenols), which help to lengthen and stabilize food storage shelf time [10]. Nonetheless, this result goes a step further to demonstrate the presence of active compounds like gingerol, shogaols, and zingerone in ginger, and curcuminoids in tumeric, which provides it with the antimicrobial properties against bacteria such as Bacillus coagulans, B.cereus, B. subtilis, Escherichia coli, Klebsiella pneumoniae, Pseudomonas aeruginosa, Staphylococcus aureus, and S. epidermidis [10,50-53].

Table 6. Antimicrobial inhibition of Ginger, Pineapple, and Tumeric Juice Mix as influenced by Blends.

\begin{tabular}{ccc}
\hline Samples (PJ:TJ:GJ) & Inhibition Zones of Juice Samples $(\mathbf{m m})$ & Control $(\mathbf{m m})$ \\
\hline 100:0:0 & 12.50 & 19.90 \\
$80: 10: 10$ & 12.00 & 19.90 \\
$70: 20: 10$ & 8.00 & 19.85 \\
$60: 30: 10$ & NSI & 19.90 \\
$50: 40: 10$ & NSI & 20.00
\end{tabular}

NSI: No Significant Inhibition. Means of two duplicate determinations. Key: PJ = Pineapple juice; TJ = Turmeric juice, GJ = Ginger juice; The control helps to show how the inhibition zone faired compared with those of the blends.

\section{Sensory Variations}

The sensory variations of ginger, pineapple, and turmeric juice mix as influenced by blends, can be seen in Table 7. The appearance scores across samples ranged from 7.87 (PJ:TJ:GJ =100:0:0) to 6.73 (PJ:TJ:GJ = 50:40:10). That of taste ranged from 7.27 (PJ:TJ:GJ $=100: 0: 0)$ to 3.80 (PJ:TJ:GJ = 50:40:10). Aroma across samples ranged from 7.33 (PJ:TJ:GJ = 100:0:0) to 5.87 (PJ:TJ:GJ = 50:40:10). Mouth feel across samples ranged from 7.40 (PJ:TJ:GJ = 100:0:0) to 4.20 (PJ:TJ:GJ = 50:40:10). General acceptability across samples ranged from 7.60 (PJ:TJ:GJ = 100:0:0) to 5.00 (PJ:TJ:GJ = 50:40:10). Besides, the sensory evaluation has a crucial role to play in judging the quality of a given food product. Control obtained peak values in aroma, mouth feel, and taste, which might have contributed to its lead overall acceptability. Increasing the turmeric and decreasing the pineapple might not necessarily make the blend juice mix more acceptable, given the decreases obtained in appearance, taste, aroma, and mouthfeel scores. Moreover, the sample blend 80:10:10 might be the more preferred compared to the others. Putting together the functional and quality data obtained thus far, we consider the turmeric, ginger, and pineapple blend juice mix nutritionally rich and consumer safe, yet, it might not be generally preferred specifically at this study.

Table 7. Sensory variations of Ginger, Pineapple, and Tumeric Juice Mix as influenced by Blends.

\begin{tabular}{cccccc}
\hline Samples PJ:TJ:GJ & Appearance & Taste & Aroma & Mouth Feel & General Acceptability \\
\hline $100: 0: 0$ & $7.87^{\mathrm{ab}}$ & $7.27^{\mathrm{a}}$ & $7.33^{\mathrm{a}}$ & $7.40^{\mathrm{a}}$ & $7.60^{\mathrm{a}}$ \\
$80: 10: 10$ & $8.27^{\mathrm{a}}$ & $5.87^{\mathrm{b}}$ & $6.67^{\mathrm{a}}$ & $6.20^{\mathrm{b}}$ & $6.33^{\mathrm{b}}$ \\
$70: 20: 10$ & $7.73^{\mathrm{ab}}$ & $4.80^{\mathrm{bc}}$ & $6.47^{\mathrm{a}}$ & $5.93^{\mathrm{b}}$ & $5.87^{\mathrm{bc}}$ \\
$60: 30: 10$ & $7.93^{\mathrm{ab}}$ & $4.47^{\mathrm{c}}$ & $5.93^{\mathrm{a}}$ & $5.73^{\mathrm{b}}$ & $5.33^{\mathrm{bc}}$ \\
$50: 40: 10$ & $6.73^{\mathrm{b}}$ & $3.80^{\mathrm{c}}$ & $5.87^{\mathrm{a}}$ & $4.20^{\mathrm{c}}$ & $5.00^{\mathrm{c}}$ \\
LSD & $1.27^{\mathrm{b}}$ & 1.18 & 1.32 & 1.15 & 1.10 \\
\hline
\end{tabular}

Values are means of two duplicate determinations. Means in the same column with the same superscript are not significantly different $(p>0.05)$, Key: PJ = Pineapple juice; TJ = Turmeric juice; GJ = Ginger juice LSD = Least significant difference. 


\section{Conclusions}

The functional and quality characteristics of ginger, pineapple, and turmeric juice mix as influenced by blend variations has been determined. The $\mathrm{Ca}, \mathrm{Mg}$, vitamin $\mathrm{C}$, and $\beta$ carotene contents increased significantly $(p<0.05)$ as quantities of pineapple and turmeric respectively decreased and increased. The degree of significant differences $(p<0.05)$ across samples appeared more in the protein, fat, and ash compared to moisture contents. Despite reducing the bacterial and fungi counts with the inhibition zone, increasing the turmeric and decreasing the pineapple might not necessarily make the blend juice mix more acceptable.

Given the blend results, the nutritional components of the juice mix blends of the current study require further exploration. For instance, the fruit genotype and climatic/storage conditions, together with different geographical regions, could be an influence on functional and quality outcomes of a given juice mix, and this warrants investigation at a future study. Another future work should target to investigate the antioxidant capacity, bioactive components, and total phenolic content of the same juice mix blends. Given the notion that many in Nigeria who take this juice mix consider it nutritionally enriching, future epidemiological and/or economic studies are warranted, as this could help provide additional information that will help substantiate this (notion). Additionally, a direction of future work could also be focused to determine the physicochemical, rheological, quality, and shelf life attributes of this blend juice mix under varying storage conditions.

Author Contributions: Conceptualization, A.F.O. and J.A.; Data curation, A.F.O., P.A. and G.B.; Formal analysis, A.F.O., J.A., P.A., G.S., C.O.R.O., G.B. and M.K.; Funding acquisition, C.O.R.O. and M.K.; Investigation, A.F.O., J.A., P.A.; Methodology, A.F.O., J.A., P.A., G.S., G.B. and M.K.; Project administration, A.F.O., J.A., P.A. and C.O.R.O.; Software, G.S., G.B. and M.K.; Validation, P.A., G.S., G.B. and M.K.; Visualization, G.S., C.O.R.O., G.B. and M.K.; Writing—original draft, A.F.O. and J.A.; Writing-review \& editing, G.S., C.O.R.O., G.B. and M.K. All authors have read and agreed to the published version of the manuscript.

Funding: Publication financed by the project UPWR 2.0: international and interdisciplinary programme of development of Wrocław University of Environmental and Life Sciences, co-financed by the European Social Fund under the Operational Program Knowledge Education Development, under contract No. POWR.03.05.00-00-Z062/18 of 4 June 2019.

Data Availability Statement: Data sharing not applicable.

Acknowledgments: The authors would like to appreciate the laboratory staff support at the Department of Food Science and Technology, Federal University of Agriculture Makurdi-Nigeria. Authors G.S. and G.B. appreciate the funding support from IRBIM-CNR - Mazara del Vallo, Italy. Authors C.O.R.O. and M.K. appreciate the funding support from Wrocław University of Environmental and Life Sciences, Poland.

Conflicts of Interest: The authors have declared no conflict of interest.

\section{References}

1. Taylor, B. Fruit and Juice Processing. In Chemistry and Technology of Soft Drinks and Fruit Juices, 2nd ed.; Ashurst, R.P., Ed.; Blackwell Publishing Ltd.: Oxford, UK, 2005; pp. 35-67. [CrossRef]

2. Mauseth, J.D. Botany, an Introduction to Plant Biology; Jomes and Barlet Publishers: Boston, MA, USA, 2003; p. 285.

3. Agada, R.E. Quality Evaluation of Juice from Blends of Cucumber and Pineapple Fruits; Department of Food Science and Technology, Federal University of Agriculture: Makurdi, Benue State, Nigeria, 2018.

4. Akusu, O.M.; Kiin-Kabari, D.B.; Ebere, C.O. Quality Characteristics of Orange/Pineapple Fruit Juice Blends. Am. J. Food. Sci. Technol. 2016, 4, 43-47. [CrossRef]

5. Offia-Olua, B.I.; Ekwunife, O. Production and evaluation of the physico-chemical and sensory qualities of mixed fruit leather and cakes produced from apple (Musa Pumila), banana (Musa Sapientum), pineapple (Ananas Comosus). Niger. Food J. 2015, 33, 22-28. [CrossRef]

6. Bhaskar, J.J.; Chilkunda, N.D.; Salimath, P.V. Banana (Musa sp. var. elakki bale) Flower and Pseudostem: Dietary Fiber and Associated Antioxidant Capacity. J. Agric. Food Chem. 2012, 60, 427-432. [CrossRef] 
7. Ogawa, E.M.; Costa, H.B.; Ventura, J.A.; Caetano, L.C.; Pinto, F.E.; Oliveira, B.G.; Barroso, M.E.S.; Scherer, R.; Endringer, D.C.; Romão, W. Chemical profile of pineapple cv. Vitória in different maturation stages using electrospray ionization mass spectrometry. J. Sci. Food Agric. 2018, 98, 1105-1116. [CrossRef]

8. Ajav, E.; Kolapo, A.; Ogunlade, C.A. Physical Properties of Ginger (Zingiber officinale). Glob. J. Sci. Front. Res. 2007, 14, 2249-4626.

9. Bailey-Shaw, Y.A.; Williams, L.A.D.; Junor, G.-A.O.; Green, C.E.; Hibbert, S.L.; Salmon, C.N.A.; Smith, A.M. Changes in the Contents of Oleoresin and Pungent Bioactive Principles of Jamaican Ginger (Zingiber officinale Roscoe.) during Maturation. J. Agric. Food Chem. 2008, 56, 5564-5571. [CrossRef]

10. Shahidi, F.; Hossain, A. Bioactives in spices, and spice oleoresins: Phytochemicals and their beneficial effects in food preservation and health promotion. J. Food Bioact. 2018, 3, 8-75. [CrossRef]

11. Varakumar, S.; Umesh, K.V.; Singhal, R.S. Enhanced extraction of oleoresin from ginger (Zingiber officinale) rhizome powder using enzyme-assisted three phase partitioning. Food Chem. 2017, 216, 27-36. [CrossRef] [PubMed]

12. Samaniego-Sánchez, C.; Inurreta-Salinas, Y.; Quesada-Granados, J.; Blanca-Herrera, R.; Villalón-Mir, M.; De La Serrana, H.L.-G.; Martínez, M.L. The influence of domestic culinary processes on the Trolox Equivalent Antioxidant Capacity of green tea infusions. J. Food Compos. Anal. 2011, 24, 79-86. [CrossRef]

13. Charles, D.J. Antioxidant Properties of Spices, Herbs and Other Sources; Springer Science \& Business Media: New York, NY, USA, 2013; ISBN 978-1-4614-4310-0.

14. Parthasarathy, V.A.; Chempakam, B.; Zachariah, T.J. Chemistry of Spices; CABI: Oxfordshire, UK, 2008; p. 464; ISBN 978-1-84593-405-7.

15. Peter, K.V. (Ed.) Handbook of Herbs and Spices, 2nd ed.; Woodhead Publishing Ltd.: Cambridge, UK, 2016; Volume 2, p. 624; ISBN 9780081016176.

16. Cheng, X.-L.; Liu, Q.; Peng, Y.-B.; Qi, L.-W.; Li, P. Steamed ginger (Zingiber officinale): Changed chemical profile and increased anticancer potential. Food Chem. 2011, 129, 1785-1792. [CrossRef]

17. Embuscado, M.E. Spices and herbs: Natural sources of antioxidants-A mini review. J. Funct. Foods 2015, 18, 811-819. [CrossRef]

18. Leja, K.B.; Czaczyk, K. The industrial potential of herbs and spices-A mini review. Acta Sci. Pol. Technol. Aliment. 2015, 15, 353-368. [CrossRef] [PubMed]

19. Yashin, A.; Yashin, Y.; Xia, X.; Nemzer, B. Antioxidant Activity of Spices and Their Impact on Human Health: A Review. Antioxidants 2017, 6, 70. [CrossRef]

20. Nisar, T.; Iqbal, M.; Raza, A. Turmeric: A promising spice for phytochemical and antimicrobial activities. Am. Eurasian J. Agric. Environ. Sci. 2015, 15, 1278-1288. [CrossRef]

21. Amalraj, A.; Pius, A.; Gopi, S. Biological activities of curcuminoids, other biomolecules from turmeric and their derivatives-A review. J. Tradit. Complement. Med. 2017, 7, 205-233. [CrossRef]

22. Sharifi-Rad, J.; El Rayess, Y.; Rizk, A.A.; Sadaka, C.; Zgheib, R.; Zam, W.; Sestito, S.; Rapposelli, S.; Neffe-Skocińska, K.; Zielińska, D.; et al. Turmeric and Its Major Compound Curcumin on Health: Bioactive Effects and Safety Profiles for Food, Pharmaceutical, Biotechnological and Medicinal Applications. Front. Pharmacol. 2020, 11. [CrossRef]

23. Idowu-Adebayo, F.; Toohey, M.J.; Fogliano, V.; Linnemann, A.R. Enriching street-vended zobo (Hibiscus sabdariffa) drink with turmeric (Curcuma longa) to increase its health-supporting properties. Food Funct. 2021, 12, 761-770. [CrossRef]

24. Muogbo, P.C.; Gbabo, A.; Nwakuba, N.R.; Onyekwere, I.; Obasa, P.A. Livelihood enhancement through mechanization of turmeric production in Nigeria. In Proceedings of the 3rd NIAE-SE Regional Conference, University of Nigeria Nsukka, Enugu State, Nigeria, 27-30 August 2018.

25. Kalaycığlu, Z.; Torlak, E.; Akın-Evingür, G.; Özen, I.; Erim, F.B. Antimicrobial and physical properties of chitosan films incorporated with turmeric extract. Int. J. Biol. Macromol. 2017, 101, 882-888. [CrossRef] [PubMed]

26. Kumar, N.; Sakhya, K.S. Ethnopharmacological properties of Curcuma longa: A review. Int. J. Pharm. Sci. Res. $2013,4,103-112$.

27. Sabale, P.; Modi, A.; Sabale, V. Curcuma longa Linn. A phytochemical and phytopharmacological review. Res. J. Pharmacogn. Phytochem. 2013, 5, 59-68.

28. Okwori, E.; Onu, R.; Adamu, M.; Chindo, H.; Dikko, H.; Odunze, I.; Baidu, A.; Natala, C.; Eze, P. Production and shelf life determination of fruit/vegetable juices using watermelon, cucumber, pineapple and carrot. Afr. J. Food Sci. Technol. 2017, 8, 34-39. [CrossRef]

29. Top 10 Home Remedies Team. Available online: https:/ / www.top10homeremedies.com/author/ap (accessed on 21 December 2020).

30. AOAC. Official Methods of Analysis of AOAC International, 18th ed.; AOAC International: Gaithersburg, MD, USA, 2005.

31. AOAC. Official Methods of Analysis of Association of Official Analytical Chemistry International, 5th ed.; AOAC International: Washington, DC, USA, 1990.

32. Ikewuchi, C.J.; Ikewuchi, C.C. Iodometric determination of the ascorbic acid (vitamin C) content of some fruits con-sumed in a university community in Nigeria. Global J. Pure Appl. Sci. 2011, 17, 47-49.

33. Iwe, M.O. Handbook of Sensory Methods and Analysis; Rejoint Communication Services Ltd.: Enugu, Nigeria, 2002.

34. Adegoke, G.O. Understanding Food Microbiology, 2nd ed.; Alleluian Ventures: Ibadan, Nigeria, 2004 ; p. 216.

35. Abubakar, S.; Akanbi, B.O.; Nasir-Naeem, K.O.; Abdulsalam, Z.N. Phytochemical and In-vitro Antibacterial Activity of the Leaves and Stem Extracts of Sesbania grandiflora (L.) against Some Clinical Isolates. Br. Microbiol. Res. J. 2015, 8, 424-433. [CrossRef]

36. Rahman, M.M.; Sheikh, M.M.I.; Sharmin, S.A.; Islam, S.; Rahman, M.A.; Rahman, M.M.; Alam, M.F. Antibacterial activity of leaf juice and extracts of Moringa oleifera Lam. against some human pathogenic bacteria. CMU J. Nat. Sci. 2009, 8, $219-227$. 
37. Balasubramanian, K. Molecular Orbital Basis for Yellow Curry Spice Curcumin's Prevention of Alzheimer's Disease. J. Agric. Food Chem. 2006, 54, 3512-3520. [CrossRef]

38. Vyas, K. The Cure is in the Roots: Turmeric. J. Nutr. Disord. Ther. 2015, 5, 3. [CrossRef]

39. Oboh, G.; Akinyemi, A.J.; Ademiluyi, A.O. Antioxidant and inhibitory effect of red ginger (Zingiber officinale var. Rubra) and white ginger (Zingiber officinale Roscoe) on Fe2+ induced lipid peroxidation in rat brain in vitro. Exp. Toxicol. Pathol. 2012, 64, 31-36. [CrossRef]

40. Achinewhu, S.C.; Hart, A.D. Effect of processing and storage on the ascorbic acid (vitamin C) content of some pineapple varieties grown in the Rivers State of Nigeria. Plant Foods Hum. Nutr. 1994, 46, 335-337. [CrossRef]

41. Rodríguez, Ó.; Gomes, W.; Rodrigues, S.; Fernandes, F.A. Effect of acoustically assisted treatments on vitamins, antioxidant activity, organic acids and drying kinetics of pineapple. Ultrason. Sonochem. 2017, 35, 92-102. [CrossRef] [PubMed]

42. Chakraborty, S.; Rao, P.S.; Mishra, H.N. Effect of combined high pressure-temperature treatments on color and nutritional quality attributes of pineapple (Ananas comosus L.) puree. Innov. Food Sci. Emerg. Technol. 2015, 28, 10-21. [CrossRef]

43. Uckiah, A.; Goburdhun, D.; Ruggoo, A. Vitamin C content during processing and storage of pineapple. Nutr. Food Sci. 2006, 39, 398-412. [CrossRef]

44. Nwaekpe, J.O.; Anyaegbunam, H.N.; Okoye, B.C.; Asumugha, G.N. Promotion of Turmeric for the Food/Pharmaceutical Industry in Nigeria. Am. J. Exp. Agric. 2015, 8, 335-341. [CrossRef]

45. Ekeledo, E.N.; Omodamiro, R.M.; Oti, E. Development and evaluation of turmeric: Ginger based pineapple drinks and food flavourings. Asian J. Plant Sci. Res. 2013, 3, 139-141. Available online: www.pelagiaresearchlibrary.com (accessed on 2 December 2020).

46. Biology_LibreTexts. Module 8.3. The Effects of $\mathrm{pH}$ and Temperature on Microbial Growth. Available online: https://bio.libretexts. org/Courses/Manchester_Community_College_(MCC)/Remix_of_Openstax\%3AMicrobiology_by_Parker_Schneegurt_et_al/ 08\%3A_Microbial_Growth/8.03\%3A_The_Effects_of_pH_on_Microbial_Growth (accessed on 15 February 2021).

47. Ehirim, F.N.; Mokorie, S.U.; Ebiringa, D.C. Effect of pineapple juice dilution of varying levels of yoghurt quality. In Proceedings of the NIFST Annual Conference, Lagos, Nigeria, 23-27 October 2006; pp. 35-36.

48. Kuttigounder, D.; Lingamallu, J.R.; Bhattacharya, S. Turmeric Powder and Starch: Selected Physical, Physicochemical, and Microstructural Properties. J. Food Sci. 2011, 76, C1284-C1291. [CrossRef]

49. Andrews, W. Manuals of Food Quality Control. 4. Microbiological Analysis; FAO Food \& Nutrition Paper 1414, Rev. 1; Food and Agriculture Organization of the United Nations: Rome, Italy, 1992; p. 344; ISBN 92-5-103189-4.

50. Gupta, A.; Mahajan, S.; Sharma, R. Evaluation of antimicrobial activity of Curcuma longa rhizome extract against Staphylococcus aureus. Biotechnol. Rep. 2015, 6, 51-55. [CrossRef]

51. Lourenço, T.; Mendonça, E.; Nalevaiko, P.; Melo, R.; Silva, P.; Rossi, D. Antimicrobial effect of turmeric (Curcuma longa) on chicken breast meat contamination. Braz. J. Poult. Sci. 2013, 15, 79-82. [CrossRef]

52. Pankaj, S.; Balqees, A.T.; Najat, A.N.; Rahma, A.M.; Sah, P.; Al-Tamimi, B.; Al-Nassri, N.; Al-Mamari, R. Effect of temperature on antibiotic properties of garlic (Allium sativum L.) and ginger (Zingiber officinale Rosc.). Afr. J. Biotechnol. 2012, 11, 16192-16195. [CrossRef]

53. Yassen, D.; Ibrahim, E.A. Antibacterial activity of crude extracts of ginger (Zingiber officinale Roscoe) on Escherichia coli and Staphylococcus aureus: A study in vitro. Indo Am. J. Pharm. Res. 2016, 6, 5830-5835. 